\title{
Clinical findings and risk factors associated with oral cancer: a prospective study
}

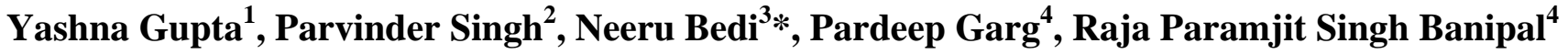

Department of Radiation Oncology, ${ }^{1}$ Delhi State Cancer Institute, New Delhi, ${ }^{3}$ GMC Patiala, Punjab, India

${ }^{2}$ Department of ENT, PCMS, Civil Hospital, Samana, Punjab, India

${ }^{4}$ Department of Radiotherapy, GGSMCH, Faridkot, Punjab, India

Received: 21 November 2017

Accepted: 05 January 2018

\section{*Correspondence:}

Dr. Neeru Bedi,

E-mail: neerubediradio@gmail.com

Copyright: ( ) the author(s), publisher and licensee Medip Academy. This is an open-access article distributed under the terms of the Creative Commons Attribution Non-Commercial License, which permits unrestricted non-commercial use, distribution, and reproduction in any medium, provided the original work is properly cited.

\begin{abstract}
Background: Oral cancer is associated with high morbidity and mortality and therefore it represents a grave health problem worldwide. However there is scarcity of the studies in the literature regarding the prognostic factors amongst the subjects. The aim of the present study is to determine the various risk factors and the most commonly affected sites by the oral squamous cell carcinoma amongst subjects of different age groups.

Methods: The present prospective comparative study was conducted at the Department of Radiotherapy at Guru Gobind Singh Medical College and Hospital during a period of three months i.e. from April 2016 to June 2016. Patients were evaluated every week for a period of approximately 2 weeks. Examination of the oral cavity was done using probe and mouth mirror by trained personnel. TNM classification was used to classify tumour. Patient's habits like alcohol and tobacco intake were also recorded. Complete demographic information was obtained from all the patients. All the data thus obtained was arranged in a tabulated form and analysed using SPSS software.

Results: The study included a total of 60 subjects. There were 11 females in the study and 49 males in the study. There were $18.3 \%(n=11)$ subjects having cancer of tongue. There were $23.3 \%(n=14)$ subjects having cancer of buccal mucosa. Alveolar ridge carcinoma was seen in $8.3 \%(\mathrm{n}=5)$ subjects. There were 22 patients $(30 \%)$ having stage III carcinoma. Majority of the subjects i.e. $70 \%(n=38)$ were at stage IV A according to TNM classification.

Conclusions: From the above study we can conclude that there is lack of awareness amongst the people about oral cancer. They mostly present during advanced stage of the disease. Most of the subjects are males, showing there predisposition towards harmful habits.
\end{abstract}

Keywords: Buccal mucosa, Cancer, Risk factors, Tongue

\section{INTRODUCTION}

Oral cancer is associated with high morbidity and mortality and therefore it represents a grave health problem worldwide. ${ }^{1}$ Majority of the oral cancers i.e. $90 \%$ are squamous cell carcinomas. ${ }^{2}$ The prognosis of this condition is poor and it has a less than $50 \% 5$ year survival rate as majority of cases are diagnosed at advanced cases. ${ }^{3}$ It affects men in their sixth and seventh decade of life. In today's time there are $4 \%$ to $13 \%$ of the cases of oral squamous cell carcinoma that affects subjects younger than 45 years of age. ${ }^{4-10}$ The most frequently affected site is tongue and it is seen generally amongst alcohol and tobacco users. ${ }^{4,5}$ Squamous cell carcinoma of lower lip is generally seen amongst subjects with exposure to sunlight. ${ }^{6}$ There has been differences in the etiological factors that are responsible for causing oral squamous cell carcinoma amongst young and elderly individuals as the young individuals are exposed to the risk factors like sunlight and tobacco for a short period of 
time..$^{9,11-15}$ Oral squamous cell carcinoma occurring amongst the younger individuals have an increased aggressiveness and poor clinical prognosis when compared to those affecting the elderly subjects. ${ }^{6,7,12,16,17}$ The prognosis of the condition is determined by the prognostic factors that would in turn determine the biological aggressiveness of the condition amongst the subjects. The various prognostic factors include regional lymph node metastasis, location of tumor and TNM classification. ${ }^{18}$ However there is scarcity of the studies in the literature regarding the prognostic factors amongst the subjects. The aim of the present study is to determine the various risk factors and the most commonly affected sites by the oral squamous cell carcinoma amongst subjects of different age groups.

\section{METHODS}

The present prospective comparative study was conducted at the Department of Radiotherapy at Guru Gobind Singh Medical College and Hospital during a period of three months i.e. from April 2016 to June 2016. The study included only histologically proven cases of squamous cell carcinoma of the head and neck. The subjects more than 18 years of age were included in the study. All the subjects were informed about the study and a written consent was obtained from all of them. Patients who are unable to understand the protocol and/or unable to provide informed consent were excluded from the study. Patients were evaluated every week for a period of approximately 2 weeks. Information was also obtained regarding the characteristics of the lesion like location of tumour, presence or absence of regional nodal metastasis. TNM classification was used to classify tumour. Patient's habits like alcohol and tobacco intake were also recorded. Complete demographic information was obtained from all the patients. All the data thus obtained was arranged in a tabulated form and analysed using SPSS software.

\section{RESULTS}

The study included a total of 60 subjects. There were 11 females in the study and 49 males in the study. The study clearly shows male predominance.

Table 1 shows the age distribution of the subjects. There were $13.3 \%(n=8)$ subjects aged between $31-40$ years. There were $25 \%(n=15)$ subjects aged between $41-50$ years. There were $26.7 \%(n=16)$ subjects aged between 51-60 years. There were $31.7 \%(n=19)$ subjects aged between $61-70$ years. There were $3.3 \%(n=2)$ subjects aged between 81-90 years. The range of age group in the present study was $35-85$ years.

Table 2 shows the distribution of the subjects according to subsite of carcinoma. There were $18.3 \% \quad(n=11)$ subjects having cancer of tongue. There were $23.3 \%$ $(n=14)$ subjects having cancer of buccal mucosa. Alveolar ridge carcinoma was seen in $8.3 \% \quad(n=5)$ subjects. Retromolar trigone carcinoma was seen in $6.7 \%$ $(n=4)$ subjects. There were 7 patients having tonsillar carcinoma. There were 11 patients having base of tongue carcinoma. There were $5 \%$ of the subjects having hard palate carcinoma. Posterior wall pharyngeal carcinoma was seen in $6.7 \%(n=4)$ subjects.

Table 1: Age distribution of the subjects.

\begin{tabular}{|lll|}
\hline \multirow{2}{*}{ Age } & \multicolumn{2}{l|}{ Study subjects } \\
\hline $\mathbf{3 1 - 4 0}$ & Number & Percentage $\mathbf{( \% )}$ \\
\hline $\mathbf{4 1 - 5 0}$ & 8 & 13.3 \\
\hline $\mathbf{5 1 - 6 0}$ & 15 & 25 \\
\hline $\mathbf{6 1 - 7 0}$ & 16 & 26.7 \\
\hline $\mathbf{7 1 - 8 0}$ & 19 & 31.7 \\
\hline $\mathbf{8 1 - 9 0}$ & 0 & 0.0 \\
\hline Total & 2 & 3.3 \\
\hline Mean \pm SD & 60 & 100.0 \\
\hline Range & $57.033 \pm 12.397$ \\
\hline
\end{tabular}

Table 2: Distribution of subjects according to subsite.

\begin{tabular}{|lll|}
\hline \multirow{2}{*}{ Subsite } & \multicolumn{2}{l|}{ Study subjects } \\
\hline Tongue & 11 & 18.3 \\
\hline Buccal mucosa & 14 & 23.3 \\
\hline Alveolar ridge & 5 & 8.3 \\
\hline $\begin{array}{l}\text { Floor of mouth } \\
\text { (FOM) }\end{array}$ & 0 & 0 \\
\hline $\begin{array}{l}\text { Retromolar } \\
\text { trigone(RMT) }\end{array}$ & 4 & 6.7 \\
\hline Tonsil & 7 & 11.7 \\
\hline Base of tongue & 11 & 18.3 \\
\hline Vallecula & 1 & 1.7 \\
\hline Hard palate & 3 & 5 \\
\hline Soft palate & 0 & 0 \\
\hline $\begin{array}{l}\text { Posterior wall of } \\
\text { oropharynx }\end{array}$ & 4 & 6.7 \\
\hline Total & 60 & 100.0 \\
\hline
\end{tabular}

Table 3: Distribution of the patients according to TNM staging.

\begin{tabular}{|lll|}
\hline \multirow{2}{*}{ Stage } & \multicolumn{2}{l|}{ Study subjects } \\
\cline { 2 - 3 } & Number & Percentage $(\%)$ \\
\hline III & 22 & 30.0 \\
\hline IVA & 38 & 70.0 \\
\hline Total & 60 & 100.0 \\
\hline
\end{tabular}

Table 3 shows the distribution of the subjects using TNM staging. Of sixty patients, patients presenting with stage IV A disease was slightly more as compared to stage III disease. There were 22 patients $(30 \%)$ having stage III carcinoma. Majority of the subjects i.e. $70 \%(n=38)$ were at stage IV A according to TNM classification. 


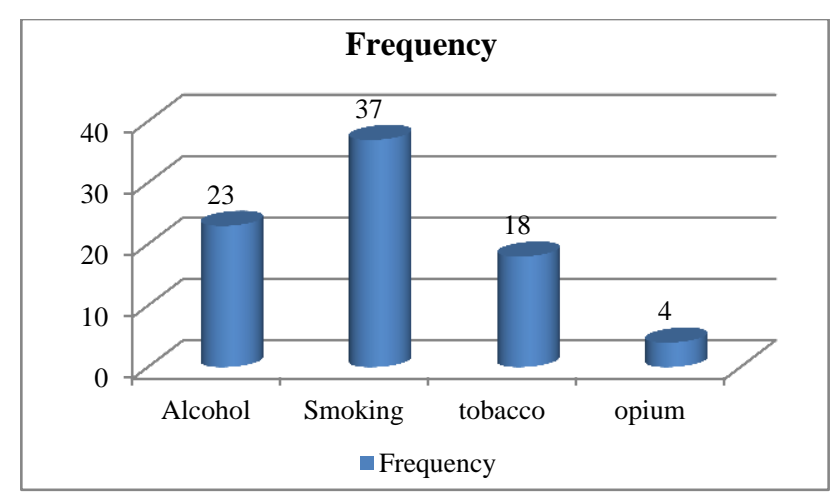

Figure 1: Addictions amongst subjects.

Figure 1 shows addictions amongst the subjects of the groups. Majority of the patients in our study had one or the other addiction. There were 23 patients addicted to alcohol. Smoking was majority of subjects i.e. there were 37 subjects who smoked. Opium addiction was seen in 4 patients. There were 18 subjects addicted to tobacco.

\section{DISCUSSION}

Since oral squamous cell carcinomas are associated with high mortality and morbidity, numerous studies should be conducted on the prevalence and risk factors. ${ }^{2}$ The control of the disease is important and there has been little to no improvements in the survival rate over the past 50 years. $^{3}$ In order to understand the changes in the profile of cancer amongst different geographic areas, epidemiological studies are important. ${ }^{19,20}$ In the present study, males were predominantly affected. There were only 11 females out of 60 that were affected by oral cancer. The studies conducted by Monteiro et al, Falaki et al and Troeltzch et al also showed male predominance in oral cancer. In our study, of sixty patients, patients presenting with stage IV A disease was slightly more as compared to stage III disease. ${ }^{11,13,14}$ There were 22 patients $(30 \%)$ having stage III carcinoma. Majority of the subjects i.e. $70 \%(n=38)$ were at stage IV A according to TNM classification. In a study conducted by Ribeiro et al and Soudry et al there was a high prevalence of oral cancer at advanced TNM stages. ${ }^{7,8}$ In a similar study conducted by Hellen-Bandeira et al, there were $60.5 \%$ cases in Stage III and stage IV. ${ }^{21}$ This clearly indicates lack of awareness amongst the subjects and aggressive nature of the condition such that most of the subjects present at advanced stage of the disease. There were $81.6 \%$ males in the study.

Majority of the patients in our study had one or the other addiction. There were 23 patients addicted to alcohol. Opium addiction was seen in 4 patients. There were 18 subjects addicted to tobacco. In a study conducted by Oliveira et al, there were $85.3 \%$ subjects who had habit of chewing or smoking tobacco. ${ }^{22}$ In their study, alcohol consumption was seen in $63.5 \%$ cases. In our study, There were $18.3 \%(n=11)$ subjects having cancer of tongue. There were $23.3 \%(n=14)$ subjects having cancer of buccal mucosa. Alveolar ridge carcinoma was seen in $8.3 \%(\mathrm{n}=5)$ subjects. Retromolar trigone carcinoma was seen in $6.7 \%(n=4)$ subjects. There were 7 patients having tonsillar carcinoma. There were 11 patients having base of tongue carcinoma. There were $5 \%$ of the subjects having hard palate carcinoma. Posterior wall pharyngeal carcinoma was seen in $6.7 \%(n=4)$ subjects. In a study conducted by Oliveira et al, the most commonly affected site was tongue $(42.5 \%){ }^{22}$ In another study conducted by Hellen-Bandeira et al tongue was the most commonly affected site followed by lower lip. ${ }^{21}$

\section{CONCLUSION}

From the above study we can conclude that there is lack of awareness amongst the people about oral cancer. They mostly present during advanced stage of the disease. Most of the subjects are males, showing there predisposition towards harmful habits. They are frequently addicted towards tobacco and alcohol consumption.

\section{Funding: No funding sources}

Conflict of interest: None declared

Ethical approval: The study was approved by the Institutional Ethics Committee

\section{REFERENCES}

1. Lambert $\mathrm{R}$, Sauvaget $\mathrm{C}$, de Camargo $\mathrm{M}$, Sankaranarayanan R. Epidemiology of cancer from the oral cavity and oropharynx. Eur J Gastroenterol Hepatol. 2011;23(8):633-41.

2. Zini A, Czerninski R, Sgan-Cohen HD. Oral cancer over four decades: epidemiology, trends, histology, and survival by anatomical sites. J Oral Pathol Med. 2010;39(4):299-305.

3. Seoane-Romero JM, Vázquez-Mahía I, Seoane J, Varela-Centelles P, Tomás I, López-Cedrún JL. Factors related to late stage diagnosis of oral squamous cell carcinoma. Med Oral Patol Oral Cir Bucal. 2012;17(1):35-40.

4. Johnson NW, Jayasekara P, Amarasinghe AA. Squamous cell carcinoma and precursor lesions of the oral cavity: epidemiology and aetiology. Periodontol 2000. 2011;57:19-37.

5. Albuquerque R, Lopez-Lopez J, Mari-Roig A, JaneSalas E, Rosello- Llabres X, Santos JR. Oral tongue squamous cell carcinoma (OTSCC): alcohol and tobacco consumption versus non-consumption. A study in a Portuguese population. Braz Dent J. 2011;22:517-21.

6. Moyses RA, López RV, Cury PM, Siqueira SA, Curioni OA, Gois Filho JF, et al. Significant differences in demographic, clinical, and pathological features in relation to smoking and alcohol consumption among 1,633 head and neck cancer patients. Clinics (Sao Paulo). 2013;68:73844. 
7. Ribeiro AC, Silva AR, Simonato LE, Salzedas LM, Sundefeld ML, Soubhia AM. Clinical and histopathological analysis of oral squamous cell carcinoma in young people: a descriptive study in Brazilians. Br J Oral Maxillofac Surg. 2009;47:958.

8. Soudry E, Preis M, Hod R, Hamzany Y, Hadar T, Bahar G, et al. Squamous cell carcinoma of the oral tongue in patients younger than 30 years: clinicopathologic features and outcome. Clin Otolaryngol. 2010;35:307-12.

9. Udeabor SE, Rana M, Wegener G, Gellrich NC, Eckardt AM. Squamous cell carcinoma of the oral cavity and the oropharynx in patients less than 40 years of age: a 20-year analysis. Head Neck Oncol. 2012;4:28.

10. Majchrzak E, Szybiak B, Wegner A, Pienkowski P, Pazdrowski J, Luczewski L, et al. Oral cavity and oropharyngeal squamous cell carcinoma in young adults: a review of the literature. Radiol Oncol. 2014;48:1-10.

11. Monteiro LS, Amaral JB, Vizcaíno JR, Lopes CA, Torres FO. A clinical-pathological and survival study of oral squamous cell carcinomas from a population of the North of Portugal. Med Oral Patol Oral Cir Bucal. 2014;19:120-6.

12. Toner M, O'Regan EM. Head and neck squamous cell carcinoma in the young: a spectrum or a distinct group? Part 1. Head Neck Pathol. 2009;3:246-8.

13. Falaki F, Dalirsani Z, Pakfetrat A, Falaki A, Saghravanian N, Nosratzehi T, et al. Clinical and histopathological analysis of oral squamous cell carcinoma of young patients in Mashhad, Iran: a retrospective study and review of literature. Med Oral Patol Oral Cir Bucal. 2011;16:473-7.

14. Troeltzch M, Knösel T, Eichinger C, Probst F, Troeltzsch M, Woodlock T, et al. Clinicopathologic features of oral squamous cell carcinoma: do they vary in different age groups? J Oral Maxillofac Surg. 2014;72:1291-300.

15. Patel SC, Carpenter WR, Tyree S, Couch ME, Weissler M, Hackman T, et al. Increasing incidence of oral tongue squamous cell carcinoma in young white women, age 18 to 44 years. J Clin Oncol. 2011;29:1488-94.
16. Mesquita JA, Queiroz LM, Silveira ÉJ, GordonNunez MA, Godoy GP, Nonaka CF, et al. Association of immunoexpression of the galectins-3 and -7 with histopathological and clinical parameters in oral squamous cell carcinoma in young patients. Eur Arch Otorhinolaryngol. 2016;273:237-43.

17. Fonseca FP, Coletta RD, Azevedo MB, Prado Ribeiro AC, Pires Soubhia AM, Miyahara GI, et al. Stromal myofibroblasts in squamous cell carcinoma of the tongue in young patients - a multicenter collaborative study. Oral Surg Oral Med Oral Pathol Oral Radiol. 2014;118:483-9.

18. Alves PM, Godoy GP, Gomes DQ, Medeiros AM, de Souza LB, da Silveira EJ, et al. Significance of galectins-1, -3, -4 and -7 in the progression of squamous cell carcinoma of the tongue. Pathol Res Pract. 2011;207:236-40.

19. Ganly I, Patel S, Shah J. Early stage squamous cell cancer of the oral tongue--clinicopathologic features affecting outcome. Cancer. 2012;118(1):101-11.

20. Kreppel M, Drebber U, Rothamel D, Eich HT, Kübler A, Scheer M, et al. Prognostic impact of different TNM-based stage groupings for oral squamous cell carcinoma. Head Neck. 2011;33(10):1467-75.

21. Hellen-Bandeira-de-Pontes Santos T, dos Santos KG, Paz AR, Cavalcanti YW, Cassiano-FranciscoWeege Nonaka GP, Godoy PM. Clinical findings and risk factors to oral squamous cell carcinoma in young patients: A 12-year retrospective analysis. Medicina oral, patologia oral y cirugia bucal. 2016;21(2):151.

22. Oliveira ML, Wagner VP, Sant'ana Filho M, Carrard VC, Hugo FN, Martins MD. A 10-year analysis of the oral squamous cell carcinoma profile in patients from public health centers in Uruguay. Brazilian oral research. 2015;29(1):1-8.

Cite this article as: Gupta Y, Singh P, Bedi N, Garg $\mathrm{P}$, Banipal RPS. Clinical findings and risk factors associated with oral cancer: a prospective study. Int J Otorhinolaryngol Head Neck Surg 2018;4:473-6. 